\title{
Choices Which Change Life Satisfaction: Similar Results For Australia, Britain And Germany*
}

\author{
Bruce Headey $^{1} \quad$ Ruud Muffels $^{2} \quad$ Gert G. Wagner $^{3}$
}

${ }^{1}$ University of Melbourne and DIW Berlin.

${ }^{2}$ Tilburg University, The Netherlands.

${ }^{3}$ DIW Berlin, Max Planck Institute for Human Development, Berlin, and Berlin University of Technology

*We would like to thank Ed Diener of the University of Illinois, Daniel Kahneman of Princeton University, Andrew Oswald of Warwick University and Alexander Wearing of Melbourne University for insightful comments on an earlier version of this paper.

\section{Abstract}

Using data from national socio-economic panel surveys in Australia, Britain and Germany, this paper analyzes the effects of individual preferences and choices on subjective well-being (SWB). It is shown that, in all three countries, preferences and choices relating to life goals/values, partner's personality, hours of work, social participation and healthy lifestyle have substantial and similar effects on life satisfaction. The results have negative implications for a widely accepted theory of SWB, set-point theory. This theory holds that adult SWB is stable in the medium and long term, although temporary fluctuations occur due to life events. Set-point theory has come under increasing criticism in recent years, primarily due to unmistakable evidence in the German Socio-Economic Panel that, during the last 25 years, over a third of the population has recorded substantial and apparently permanent changes in life satisfaction (Fujita and Diener, 2005; Headey, 2008a; Headey, Muffels and Wagner, 2010). It is becoming clear that the main challenge now for SWB researchers is to develop new explanations which can account for medium and long term change, and not merely stability in SWB. Set-point theory is limited precisely because it is purely a theory of stability. The paper is based on specially constructed panel survey files in which data are 
divided into multi-year periods in order to facilitate analysis of medium and long term change.

JEL Classification: I31, J1, Z13

Key words: set-point theory, life goals/values, individual choice, panel regression analysis, BHPS, HILDA, SOEP 


\section{Choices Which Change Life Satisfaction: Similar Results For Australia, Britain And Germany}

The focus of this article is on individual preferences and choices - relatively unconstrained choices - which make a substantial difference to life satisfaction. These choices relate to (1) life goals/values (2) the personality of the partner one lives with (3) hours of work and leisure (4) social participation and (5) healthy lifestyle. If it can be shown that these personal and work choices are consequential, the results will have major implications for the still dominant theory of subjective well-being (SWB), set-point theory. Set-point theory holds that adults have stable levels of SWB, which depend on genetic factors, including personality traits (Brickman and Campbell, 1971; Headey and Wearing, 1989; Lykken and Tellegen, 1996). It is accepted that major life events (viewed as exogenous shocks) can produce temporary fluctuations in SWB, but the theory predicts, and it has been convincingly demonstrated, that following most events most individuals revert within a year or two to their previous set-point (for an up-to-date review see Clark, Diener and Lucas, 2008). Clearly, a major implication of set-point theory is that individual choices could not make much difference to SWB.

In analyzing data from Australian, British and German panel surveys, our strategy will be to show that individual choices matter, controlling for fixed genetic and personality factors which set-point theory highlights, and which must clearly be regarded as causally antecedent to choices which individuals make. The panel data allow us to analyze the extent to which, net of genetic factors, changes in individual choices have been associated with changes in SWB. The sample for each country comprises prime age adults (25-64); the age group whose SWB set-points are not supposed to change.

In the last few years there have been several critiques and attempts to revise set-point theory, which have exposed its serious limitations (Easterlin, 2005; Diener, Lucas and Scollon, 2006; Headey, 2006, 2008a; Lucas and Donnellan, 2007; Headey, Muffels and 
Wagner, 2010). Set-point theory is purely a theory of stability. It depends on finding or assuming that adult SWB is stable. Until long term panel data became available, long term stability could not be directly tested. In practice it was just inferred from observations of the short-lived effects of life events, from personality studies, twin studies and relatively short term SWB panels (Brickman and Campbell, 1971; Headey and Wearing, 1989; Lykken and Tellegen, 1996). But analysis of Australian, British and German panel data has now shown that assumptions and inferences about stability can no longer be maintained (Ehrhardt, Saris and Veenhoven, 2000; Fujita and Diener, 2005; Headey, 2006, 2008a; Headey, Muffels and Wagner, 2010). Evidence from the German panel, which has now run for 25 years (1984-2008), is particularly convincing. Headey, Muffels and Wagner (2010) based their analysis of change on five-year averages of individuals' life satisfaction scores. Comparing the first five-year period (1984-88) with the last (2004-08), it was found that $38.1 \%$ of the population changed their position in the life satisfaction distribution by 25 percentiles or more, $25.5 \%$ changed by 33.3 percentiles or more, and $11.8 \%$ changed by 50 percentiles or more (e.g. from the $25^{\text {th }}$ to the $75^{\text {th }}$ percentile or vice-versa). Comparable changes, although for shorter periods, are found in the Australian and British data (Headey, 2006). Changes of this magnitude recorded by a substantial segment of the population cannot be reconciled with set-point theory as currently understood.

So the research challenge now is to develop a new theory, which accounts for change as well as stability (Gigerenzer, 2010). It seems to be the case, at least in Australia, Britain and Germany, that a majority of people maintain fairly stable set-points. ${ }^{1}$ But SWB theory also needs to account for the large minority whose set-points change. To be more exact, the focus needs to be on medium and long term change; we already know that temporary fluctuations are caused by life events.

Before discussing hypotheses about the causes of medium term change, it is important to record some additional limitations of set-point theory highlighted by recent research and

\footnotetext{
${ }^{1}$ Even this degree of stability might not hold in a country with a more turbulent recent history. In the periods in question none of these countries experienced a major war, nor a major economic recession.
} 
reviews. Despite occasional claims that genetic factors account for almost all the variance in SWB (e.g. Lykken, 1999), most reviews conclude that only about 40-50\% of the variance can be accounted for (Huppert, 2005; Lucas, 2008). To put this another way, it is clear that many people who appear to have just the 'right' kind of personality to rate high on life satisfaction (e.g. they rate high on extroversion and low on neuroticism) are in fact in the bottom half of the distribution, and many individuals with apparently unfavourable personality traits are high in the distribution (Headey, 2006; Diener and Diener, 2008).

Ed Diener and colleagues have repeatedly sought to explain changes in SWB by tracking the effects of a range of life events on the time profile of SWB scores; scores before, close to and after the event (Lucas, Clark, Georgellis and Diener, 2003; Clark, Georgellis, Lucas and Diener, 2004; Clark, Diener and Lucas, 2008). They have drawn somewhat varying conclusions from this research. Their latest comprehensive assessment is that only one fairly common event, persistent or repeated unemployment, can be shown to have a long term effect on SWB (Clark, Diener and Lucas, 2008). Earlier they had reported that several other events, notably getting married and becoming widowed, appeared to have long term effects on some individuals, although not all (Lucas, Clark, Georgellis and Diener, 2003). Currently, however, the conclusion being drawn, or perhaps left open to inference, is that because most life events - events which one would think of as major landmarks in a person's life - do not produce lasting change in SWB, then set-point theory does not need serious revision (Clark, Diener and Lucas, 2008). This seems dubious. Based on national panel evidence, the current state of play is surely that we know that substantial medium and long term changes in SWB do occur, but attempts to explain these changes in terms of one-off life events have largely failed.

So what else might account for persistent change? Richard A. Easterlin (2005), in a wide-ranging literature review, marshalls evidence to show that persistent change is quite likely to occur in the health and family domains, but not in the financial domain. The evidence relating to health, and specifically to chronic conditions (as opposed to one-off health events) is particularly convincing. Late onset health conditions, including type 2 
diabetes and arthritis, appear to permanently lower SWB (Mehnert et al, 1990; Lucas, 2007). This is not to deny that partial adaptation/habituation occurs, but complete adaptation does not. Easterlin's view that chronic conditions, as distinct from one-off events, may help to account for change is congruent with the well established finding that parents never fully recover from the untimely death of a child; the chronic condition here being unresolved grief (Wortman and Silver, 1987).

In searching for other factors which might account for persistent change in the German data, Headey (2006) found that individuals with certain personality traits appear more open to long term change than others. Highly extroverted people are more likely to have recorded long term gains in life satisfaction, and more neurotic people are more likely to have sustained long term losses. The mechanisms are far from certain. It is known that extroverted people are more likely to perceive and record positive experiences than introverts and also tend to react more strongly in a positive direction to those experiences (Larsen and Ketelaar, 1991; Rusting and Larsen, 1997; Lucas and Baird, 2004). In parallel fashion, individuals who rate high on neuroticism perceive and record more negative experiences and react worse to them than most other people (Larsen, 1992). What remains unknown, however, is why (if it is true) some individuals with these traits record persistent changes in SWB, rather than reverting to their previous set-points.

This paper extends previous research on the significance of life goals/values for SWB. Several papers have shown that giving top priority to material goals/values is inimical to happiness (Nickerson et al, 2003; Diener and Seligman, 2004; Kasser and Kanner, 2004). Experimental and survey evidence indicate that people who spend more money on others and relatively less on themselves have higher life satisfaction (Dunn, Aknin and Norton, 2008). Headey (2008b) reported that individuals who give relatively high priority to social, altruistic goals and family (quality of relationship) goals, and lower priority to material and career goals, are more satisfied with life initially and that this difference increases over time (see also Emmons, 1986). These results held, controlling for the effects of personality traits. Several studies have indicated that volunteering, engaging in altruistic community activities and repeatedly carrying out 'good deeds' are associated 
with higher SWB (Harlow and Cantor, 1996; Thoits and Hewitt, 2001; Lyubomirsky, 2008).

In trying to explain why people who give priority to social/altruistic and family goals appear more satisfied than those who prioritise material and career goals, Headey (2008b) suggested that a key distinction may lie between zero sum and non-zero sum goals. ${ }^{2}$ Generally speaking, material and career goals (also status goals) are zero sum. They can only be pursued at the expense of someone else; 'my gain is your loss'. It follows that there are bound to be many losers and that almost all those who win in round 1 will lose in round 2 or later rounds. So, on average and for most people, prioritising zero sum goals may turn out to be a recipe for disappointment rather than life satisfaction. By contrast, family goals and pro-social goals are generally (although not necessarily) nonzero sum. If family relationships improve, or pro-social goals are achieved, everyone can be better off; there do not have to be any losers.

This article extends the same line of inquiry by assessing the effects of additional priorities which seems likely to lead to non zero sum gains. It is hypothesized that individuals who choose (or are chosen) by partners with 'benign' personalities will have higher life satisfaction - net of their own personality traits - than individuals who choose partners with unfavourable personalities. Specifically, it is hypothesized that individuals whose partners are low on neuroticism (the trait most strongly correlated - negatively correlated - with SWB) will be happier than those whose partners are relatively neurotic. This result has been found in relation to marital satisfaction, so it seems plausible to extend the same idea to SWB (Robins, Caspi and Moffitt, 2000). Previous SWB research has shown that the life satisfaction and marital satisfaction of partners are quite highly correlated, although their satisfaction does not become more similar over time (Schimmack and Lucas, 2010). There has also been a great deal of research on whether people with similar personality traits tend to partner/marry each other (Robins, Caspi and Moffitt, 2000). They do, but the correlations between partners' ratings on all traits,

\footnotetext{
${ }^{2}$ See also Hirsch (1976) and Frank (1985) who make a similar distinction between positional and nonpositional goods.
} 
including neuroticism, are typically quite modest. Finally, it is known that people who have been happier as single people are subsequently likely to make happier marriages (Lucas, Clark, Georgellis and Diener, 2003; Lyubomirsky, 2008). However, there appears to be little previous evidence on the issue of whether partner personality traits significantly affect one's own life satisfaction over and above one's own traits. We found this to be true for Germany (Headey, Muffels and Wagner, 2010) and here we provide replicatory evidence for Australia and Britain. The evidence that partner traits matter will lead us to a reinterpretation of the view that getting married/partnered usually only produces a temporary gain in life satisfaction (Campbell, Converse and Rodgers, 1976; Clark, Diener and Lucas, 2008).

Now an economic choice: welfare economics is based on the assumption that the main choice or trade-off which individuals make in trying to maximize their welfare or utility lies between work and leisure. Paid work is necessary to finance consumption, while leisure time (it is assumed) generates pleasure. The validity of this trade-off assumption has not been directly tested, using life satisfaction measures, or what economists are now calling subjective measures of utility (Frey and Stutzer, 2002). In this article we use the three national panels to show that changes in the fit between a person's preferred and actual working hours - and so, by implication, their preferred and actual hours of leisure can change life satisfaction.

Another matter of individual choice is the extent to which one spends leisure time participating in social and community activities. There is abundant evidence that individuals with richer social networks or more social capital enjoy great life satisfaction (Bradburn, 1969; Putnam, 2000; Diener and Diener, 2008). The panel datasets go beyond measuring static social networks and provide annual measures of frequency of social interaction with friends, relatives and neighbors. It is hypothesized that active participation is positively related to life satisfaction. Note that social and community participation can be viewed as another field (or life domain) in which non zero sum gains are likely to be available. 
The health domain is also non zero sum; plainly, gains to my health are unlikely to be associated with consequent losses to anybody else's health. Further, adopting a healthy lifestyle is, for most Western people, a matter of relatively free choice. The panel datasets include two variables related to healthy lifestyle; frequency of exercise and BMI (weight relative to height). Much previous research has naturally been concerned with the impact of exercise, BMI and other lifestyle variables on health rather than life satisfaction. Reviews of the evidence relating to satisfaction have generally suggested positive relationships, but with an important 'reverse causation' caveat, namely that people who are happier in the first place may choose more exercise and a healthier diet (Diener and Diener, 2008). Here it is hypothesized that healthy lifestyle promotes life satisfaction, net of personality traits, life goals and other antecedent variables. This approach does not rule out the possibility of some reverse causation, but a more plausible interpretation (it is suggested) is that personality traits are causally antecedent and affect both choice of lifestyle and satisfaction.

The aim then is to move towards developing a theory of stability and change - especially medium and long term change - in SWB. The best available datasets for this purpose are panel surveys in which questions on SWB (life satisfaction) have been asked for many years on an annual basis. The three most readily available are the Australian (HILDA) panel, the British (BHPS) panel and German (SOEP) panel. It is particularly helpful that these datasets have been made more comparable, or 'harmonized', via being included in the Cross-National Equivalent File (CNEF) distributed by Cornell University. ${ }^{3}$

\section{METHODS}

\section{The Australian (HILDA), British (BHPS) and German (SOEP) Socio-Economic \\ Panels}

The German (SOEP) panel is the longest running of these national household panels. It began in 1984 in West Germany with a sample of 12541 respondents (Wagner et al., 2007). Interviews have been conducted annually ever since. Everyone in the household

\footnotetext{
${ }^{3}$ The CNEF can be obtained from Cornell University at www.human.cornell.edulpam\researchlcentersprogram/.../cnef.cfm
} 
aged 16 and over is interviewed; here we make particular use of the data on the personality traits of spouses. The cross-sectional representativeness of the panel is maintained by interviewing 'split-offs' and their new families. So when a young person leaves home ('splits off') to marry and set up a new family, the entire new family becomes part of the panel. The sample was extended to East Germany in 1990, shortly after the Berlin Wall came down, and since then has also been boosted by the addition of new immigrant samples, a special sample of the rich, and recruitment of new respondents partly to increase numbers in 'policy groups'. There are now over 60,000 respondents on file, including some grandchildren as well as children of the original respondents. The main topics covered in the annual questionnaire are family, income and labor force dynamics. A question on life satisfaction has been included every year.

The British (BHPS) panel was launched in 1991 with about 10, 300 individuals in 5,500 households (Lynn, 2006). However, a question about life satisfaction was not included until 1996, so in this paper only 1996-2007 data are used. As in Germany, all individuals in the household who are aged 16 and over are interviewed. Again, sample representativeness is maintained by including split-offs and their new households. The British panel has been augmented by booster samples for Scotland and Wales in 1991 and a new Northern Ireland sample in 2001. In 2007, the latest year used in this paper, the sample size was just over 14,000. A major change occurred in 2010 when the BHPS panel was merged into the new United Kingdom Household Longitudinal Study ('Understanding Society'), which included a great many additional questions, especially in the health area. The new sample size is expected to be about 100,000.

The Australian (HILDA) panel began in 2001 with a sample of 13,969 individuals in about 7,700 households (Watson and Wooden, 2004). Interviews were achieved in $61 \%$ of in-scope households. In the Australian panel all household members aged 15 and over are interviewed. Using following rules similar to Germans and British, individuals who split off from their original households continue in the panel, and members of their new households join it. In 2009 (the latest available year), interviews were conducted with 13,301 individuals in 7,234 households. It may be noted that, as happens in all panels 
with good retention rates, the sample size is now increasing. That is, the number of individuals added to the panel each year, via split-offs and young people turning 15 , exceeds the number who die, cannot be traced, or drop out by refusing an interview. The Australian panel has not yet been 'refreshed'; a major boost, including adequate numbers of new immigrants, is planned for 2012.

For this paper the sample in each country is restricted to prime age adults, defined as those aged 25 to 64 . The aim is to restrict analysis to mature age individuals who, according to set-point theory, should have stable levels of SWB. The lower age limit excludes younger individuals whose personalities may still be changing. The top limit excludes senior citizens who might find it odd to talk about life goals/priorities, especially career goals, in the later part of their life when most are retired. Further, it is known that life satisfaction declines in the last few years of life as health declines (Gerstorf et al, 2010).

\section{Measures}

The research teams which run the three panels have developed slightly differing measures for most concepts used in this paper. However, despite differences of language, question wording and response scales, we shall find that our main empirical results (with a single exception relating to life goals) replicate across the three countries. This issue is discussed further in the concluding section.

\section{Life satisfaction}

The dependent (outcome) variable in all equations is life satisfaction measured in Australia and Germany on a 0-10 ('totally dissatisfied' to 'totally satisfied') scale. In Britain a 1-7 scale is used. This has been transformed to run from 0-10 to make the British results more readily comparable with the other two countries.

Single item measures of life satisfaction are plainly not as reliable or valid as multi-item measures, but are widely used in international surveys and have been reviewed as acceptably valid (Diener et al, 1999). 


\section{Personality traits}

In 2005 the research teams running the three panels more or less copied each other and included a full set of personality measures for the first time. The chosen instrument in each country was a short version of the Big Five Personality Domains - NEO-AC (Costa and McCrae, 1991). The traits in the Big Five are neuroticism, extroversion, openness, agreeableness and conscientiousness. The British and German panels included very short versions of the five scales - just three items/questions to measure each trait - which are reported to be satisfactorily reliable and to correlate highly with longer versions of the NEO-AC preferred by psychologists (Gerlitz and Schupp, 2005). ${ }^{4}$ The Australian panel included seven items per trait (Saucier, 1994).

Psychologists usually take the view that personality is about $40-50 \%$ hereditary and quite stable, at least from the age of about 25 or 30 onwards (Roberts, Walton and Viechtbauer, 2006). It should be stressed that, by including personality traits measured in 2005 on the right hand side of equations to account for life satisfaction in earlier as well as later years, we are in effect assuming that personality is completely stable. If it were completely stable, then of course it would not matter when it was measured. However, the assumption is not entirely correct. It is thought that ratings on personality traits might be changed to a moderate degree by life experiences like having a stable marriage or an absorbing job (Roberts, Walton and Viechtbauer, 2006; Scollon and Diener, 2006).

\section{Life goals/values}

SWB researchers are understandably keen to measure what are variously termed life goals or life priorities or values. However, it has proved difficult to obtain valid measures. In a very thorough investigation, two pioneers of SWB research, Andrews and Withey (1976) reported that measures of the priority attached to goals, asked on scales running from 'very important' to 'not at all important', appeared to suffer from social desirability bias, with respondents all giving high ratings to family goals. Importance scores also had low test-retest reliability. A further possible problem was that importance

\footnotetext{
${ }^{4}$ Even the short version of the scale released by Psychological Assessment Resources has 60 items; 12 items per trait (Costa and McCrae, 1991).
} 
scores and satisfaction scores in most life domains turned out to be moderately correlated. This might mean that people were quite good at getting what they wanted in life - a result in line with economists' utility maximization assumption - or might suggest some reverse causation, with respondents tending to impute importance to domains they were already well satisfied with, perhaps as a psychological mechanism to boost their overall life satisfaction (Andrews and Withey, 1976). In general, respondents whose life satisfaction was high tended to rate most domains as very important, whereas unhappy or depressed respondents tended (presumably as a consequence of unhappiness) to rate most domains as relatively unimportant. An underlying problem, which may partly account for measurement difficulties, is probably that most people are not of a philosophical bent and do not regularly think about their life priorities.

The German panel group decided to tackle these issues afresh and appears to have made considerable improvements in goals/values measurement. Their approach is based on a classification of goals/values initially developed by Kluckhohn and Strodtbeck (1961). Kluckhohn and Strodtbeck set out to measure three sets of goals/values:

- material goals/values and career success

- family goals/values: marriage, children and the home

- pro-social or altruistic goals/values: friendship, helping others, social and political activism.

Using this framework, the German research group developed survey items which have a stable factor structure and adequate test-retest reliability (Wagner et al., 2007). Goals have been measured intermittently (rather than annually) in SOEP, starting in 1990. The specific questions asked in different waves of the survey have varied somewhat; here we will use data from the 1990, 1992, 1995, 2004 and 2008 surveys in which the questions were nearly identical. In these surveys 9 or 10 items were included $^{5}$, all asked on a 1-4 scale running scale running from 'very important' to 'not at all important'. In each wave the items formed three distinct, replicating factors: a material goals/values factor, a

\footnotetext{
${ }^{5}$ Ten items were included in 1990, 1992 and 1995 and then nine in 2004 and 2008. The item dropped in 2004 and 2008 related to the importance of having a wide circle of friends, which loaded on the pro-social factor.
} 
family goals/values factor and an pro-social or altruistic goals/values factor (Headey, 2008b). Material goals may be viewed as zero sum, whereas family goals and pro-social goals are non-zero sum.

The material goals index which gave equal weight to 'being able to buy things', and 'success in your job'. Similarly a family goals index was constructed which gave equal weight to items relating to the importance of marriage and children items. Finally, the pro-social/altruistic goals index gave equal weight to 'being involved in social and political activities' and 'helping other people'.

The Australian panel has included questions on life goals only once (2001), and the British panel only twice $(1998,2003)$. Rather than follow the German panel approach of measuring goals according to an a priori classification, these two research teams have reverted to the earlier approach of presenting respondents with a rather miscellaneous set of goals. Since the purpose of this article is to assess whether determinants of life satisfaction replicate cross-nationally, the analysis will include only goals similar to those classified by the German research group. In the British panel questions were asked on a 1-10 scale ('not at all important' to 'very important'). Respondents rated the importance to them of 'money' (material goal/value), 'a good partnership' and 'having children' (family goals/values) and 'good friends' (friendship goal, but without a community participation aspect). In the Australian survey questions were included about the various goals on a 0-10 scale ('not at all important' to 'very important'). Key items related to the importance of 'your family' (family goals) and 'involvement in your local community' (community goal but without a friendship aspect). The question intended to tap into material goals/values was somewhat ambiguous. Respondents rated the importance of 'your financial situation'. This item could have assessed the extent to which respondents were concerned or worried about their financial situation, rather than, or as well as, the priority they attached to material goals.

We have not attempted to assess the effects of changes in life goals/values in this paper. Because the questions have only been asked once in Australia, twice in Britain and 
intermittently in Germany, the data are not really suited to analysis of change. Instead we have averaged respondents' scores on goals for the waves in which they participated.

\section{Preferred and actual working hours}

The trade-off between paid work (or rather the consumption that work pays for) and leisure is central to welfare economics. Respondents in the Australian and German panels are asked both how many hours per week they actually work (in all jobs combined, if they have more than one job), and how many they would prefer to work. The gap between these two figures can be treated as a rough measure of the degree to which they are achieving their preferred trade-off/choice between work and leisure. Here we classify individuals whose actual working time is within three hours of their preferred time as having their preferences met. We treat those who work over three hours more than they want as 'overworked', and those who work over three hours less than they want as 'underworked'. Other hours 'gaps' were tested, but the 3-hour variables showed the highest correlation with life satisfaction.

In the British panel respondents are asked how many hours they work (in all jobs combined), and whether they would prefer to work more hours than they do now, fewer, or the same. They are not asked precisely how many hours they would prefer to work, so designating them as 'overworked', 'underworked' or having their preferences met is a somewhat cruder exercise than in the Australian and German files.

\section{Social participation}

The three panel surveys also differed somewhat in how they measure participation in social activities. In the Australian panel respondents are asked a single question about how frequently they meet with 'friends and relatives'. The response scale runs from 1 (every day) to 7 (less than every 3 months). ${ }^{6}$ In the British panel there are two separate items, one relating to frequency of 'meeting with friends and relatives' and one to frequency of 'talking with neighbors'. These are asked on a response scale running from

\footnotetext{
${ }^{6}$ For each country response scales relating to social participation have been reversed so that a high score reflects high participation.
} 
'on many days' (code 1) to 'never' (code 5). For present purposes these highly correlated items have been combined into a social participation index. In the German panel our social participation index used here combines two correlated items about frequency of 'meeting with friends, relatives or neighbors' and 'helping out friends, relatives or neighbors'. 7 The response scale has just three points: 'every week', 'every month' and 'seldom or never'. 8

An advantage is that the social participation questions have been asked every year in all three panels.

\section{Healthy lifestyle}

In all three panels the only 'healthy lifestyle' questions which have been asked repeatedly (but not in the British survey annually) relate to participation in sport and/or exercise. Again, questions differ slightly. In the Australian panel respondents are asked about how frequently they take moderate or intensive physical activity lasting for at least 30 minutes. The response scale runs from 0 ('not at all') to 5 ('every day'). In the British panel time use questions receive more attention than in the other two panels. A question is asked every two years about how often respondents walk, swim or play sport. The 5point response scale runs from 'at least once a week' to 'never/almost never'. Finally, in the German dataset there is an annual question about participation in active sport or exercise. The 1-4 response scale runs from 'almost never' to 'at least once a week'.

A second healthy lifestyle measure, Body-Mass Index (BMI), has only been included in the panels in recent years (and even then not every year). BMI measure the appropriateness of weight for height. A BMI between 18.5 and 24.9 is considered 'normal', under 18.5 is 'underweight', 25.0 to 29.9 is 'overweight' and $30+$ is 'obese'.

\footnotetext{
${ }^{7}$ The correlations have varied from year to year but are usually around 0.3 .

8 'Seldom' or 'never' have been included as separate categories in more recent waves of SOEP.
} 


\section{Data analysis based on moving three or five-year averages of life satisfaction}

Almost all longitudinal analyzes of individual or household panel data are based on annual waves, reflecting the time interval at which data are actually collected. But it is already known that annual changes in life satisfaction are mainly just temporary fluctuations due to life events. In this paper our aim is to account for medium term stability and change, so it was appropriate to base analysis on medium term periods of life satisfaction. In practice, we used five-year moving averages of life satisfaction (1984-88, 1985-89, 1986-90 and so on) for analyzing the German data, and three-year moving averages for the shorter Australian and British panels. The purpose of taking multi-year averages is to iron out temporary fluctuations. The procedure is similar to that used by economists, who commonly take multi-year periods of income, in order to assess changes in medium or long term ('permanent') income. Intuitively, five years periods seem appropriate when writing about medium term change. However, the Australian and British panel data are only available for nine and twelve years respectively, so we settled for three-year moving averages.

In summary, the dependent (outcome) variables in all analyzes in the paper are three or five-year moving averages in the life satisfaction scores of panel members. We then use respondents' annual scores for independent (explanatory) variables to try and account for medium term change.

It should also be noted that values for some explanatory variables which were not included in every wave of the panel surveys have been imputed. Oddly, the life satisfaction question was omitted from the British survey in 2001. We have simply averaged results for 2000 and 2002 to provide 2001 values. More importantly, the NEOAC has been asked only once in each panel (in 2005), so we needed to assume that personality is stable and impute it for all other years. Not to have done so would have voided all longitudinal analyzes.

In any panel survey, what are called 'panel conditioning effects' are a possible source of bias. That is, panel members might tend to change their answers over time - and answer 
differently from the way non-panel members would answer - as a consequence just of being panel members. In all three panels there is some evidence that panel members, in their first few years of responding, tend to report higher life satisfaction scores than when they have been in the panel for a good many years (Frijters, Haisken-DeNew and Shields, 2004). This could be due to 'social desirability bias'; a desire to look good and appear to be a happy person, which is stronger in the first few years of responding than in later years. Or it could be due to a 'learning effect'; learning to use the middle points of the 010 or 1-7 scale, rather than the extremes and particularly the top end.

To compensate for these possible sources of bias, we include in all equations a variable which measures the number of years in which each panel member has already responded to survey questions.

\section{RESULTS}

The sequence of models and commentaries presented in this section reflects an assumed temporal and causal sequence. It is assumed that an individual's own personality traits are substantially hereditary and that they, along with other fixed characteristics like gender and ethnicity, should be controlled in subsequent models which include choices relating to partner characteristics, life goals/priorities and so forth. Later it is assumed that both personality traits and life goals/values should be regarded as causally antecedent to choices about working hours, social participation and 'healthy lifestyle'.

\section{Effects of Own and Partner's Personality Traits on Life Satisfaction}

For each country, Table 1 shows the effects of one's own and partner personality traits (NEO-AC) on life satisfaction. The main interest lies in the effect of partner traits, since it is already well known that one's own traits make a substantial difference. However, the first column of results for each country shows just the effects on satisfaction of an individual's own traits, plus a set of 'control' variables. In all subsequent analyzes we will need to net out the effects of a person's own traits plus controls in order to assess the impact of personal and work choices on life satisfaction. The controls included in all models are: gender, age, age squared and age cubed (to allow for a decline in satisfaction 
in middle age and a rise in senior years $)^{9}$, marital/partnership status, having a health disability, the national unemployment rate, being East German (Germany only), foreign born (Germany only), being from a non-English speaking background (Australia only), non-white (Britain only), and 'number of years already a panel respondent'. It was decided not to include level of formal education, occupational status or household income as controls because they could well be partly consequences rather than antecedents of personality traits and life goals. It should be noted, however, that if these extra controls are (mistakenly?) included, then all results given below remain substantially unchanged.

Table 1 for each country reports results for the whole sample and then separately for partnered men and partnered women. As noted above, the results of main interest (columns 2 and 3) relate to partnered people and show evidence of the effects of partner personality traits on life satisfaction, net of the effects of one's own traits. These are Generalized Least Squares (GLS) random effects regressions, which make use of all years of panel data, but should be viewed as yielding static rather than longitudinal results because personality traits (the explanatory variables of main interest) are assumed to be stable. This and all subsequent tables report metric (unstandardized) coefficients.

\section{INSERT TABLE 1 FOR EACH COUNTRY HERE}

It has long been known that the personality traits of neuroticism $(\mathrm{N})$ and extroversion $(\mathrm{E})$, especially N, are quite strongly related to SWB (Costa and McCrae, 1980). Results from all three national panels indicate that traits agreeableness (A) and conscientiousness (C) are favourable for SWB. The results relating to $\mathrm{A}$ and $\mathrm{C}$ have also been found in several population surveys (Lucas, 2008). In most surveys trait openness (O) is found to be unrelated to SWB and this is the result that should probably be accepted (Headey and Wearing, 1989; Lucas, 2008). The three panels, using short scales, actually produce contradictory findings in relation to $\mathrm{O}$. The British panel shows no statitistically significant link between $\mathrm{O}$ and life satisfaction, the German panel shows a small but

\footnotetext{
${ }^{9}$ Many papers only include an age squared term. However, if it is hypothesized that satisfaction declines in middle age and then rises again in one's senior years, then logically an age cubed term is required as well.
} 
statistically significant positive relationship, and the Australian panel finds a small and significant negative relationship.

The somewhat new and quite important results in these three tables relate to partnered people. It is clear that partner's level of neuroticism has a negative and significant effect $(\mathrm{p}<0.001)$ on an individual's own SWB, over and above his/her own traits. Other partner traits appear not to matter much, although in Australia and Britain partner conscientiousness (C) has a positive effect, which is just statistically significant. It is possible that this is due to conscientiousness being related to higher earnings (Barrick and Mount, 1991).

A hypothesis sometimes put forward is that partners who have similar personalities are likely to be suited to each other and may have higher SWB as a consequence (Robins, Caspi and Moffitt, 2000). ${ }^{10}$ This hypothesis was tested by constructing a partner similarity/difference score for each of the five traits. When these variables were added to the equations, none of them accounted for significant additional variance. In other words, the evidence indicates that the extent to which partner personality is favourable to SWB matters, but personality similarity between partners offers no additional benefits. Robins, Caspi and Moffitt (2000) report a similar finding in relation to marital satisfaction.

Because adult personality is fairly stable, a key implication of these results is that partnering a person with traits positively correlated with SWB will bring about a long term improvement in one's own SWB, whilst partnering a person with traits negatively correlated with SWB will bring about a long term loss. To test these inferences, separate equations were run for German partners who had lived together for less than 5 years, 5-10 years, 10-20 years, and over 20 years. It was hypothesized that gains and losses to SWB might diminish the longer one remained with the same partner. This proved not to be the case. In all sub-groups partner personality, especially trait $\mathrm{N}$, made a substantial difference to SWB.

\footnotetext{
${ }^{10}$ An alternative hypothesis is that 'unlike poles attract' and that partners with contrasting personalities will get on better together and have higher SWB. This hypothesis was also tested and rejected via the partner similarity/difference scores constructed here.
} 
These results are contrary to some previous research which has found that 'getting married' usually produces only a one or two year gain in SWB, after which people revert to their previous set point (Clark, Diener and Lucas, 2008). The issue of reconciling previous evidence about the short term effects of 'getting married' with the evidence here is fairly straightforward and will be taken up in the Discussion section.

\section{Effects of Life Goals/Values and Partner's Life Goals/Values on Life Satisfaction}

Table 2 for each country gives results relating to the impact of one's own and partner's life goals/values on life satisfaction. Personality traits (and standard demographics) are treated as antecedent to life goals and so are included in the equations as controls. In Table 2 results are also based on Generalized Least Squares (GLS) random effects regression equations.

\section{INSERT TABLE 2 FOR EACH COUNTRY HERE}

The evidence here indicates that people who prioritize non zero sum pro-social, altruistic goals or family goals are more satisfied with life than people who prioritize zero sum goals relating to material success and careers. It appears that pro-social goals can make a substantial contribution to SWB, whereas material goals are not helpful to life satisfaction and may actually be harmful (Nickerson et al, 2003; Diener and Seligman, 2004; Headey, 2008b). The German and British results actually show a significantly negative relationship between giving priority to material goals and life satisfaction, whereas in Australia (where the question relating to material goals was ambiguous), there appears to be essentially no relationship.

Somewhat speculatively, we also included measures of partner's life goals/values in the equations underlying these tables. In Germany, where goals/values were more carefully measured, the signs of the coefficients for partners were the same as those for a person's own goals. Men and women whose partners gave priority to family goals/values rated 
significantly higher than average on life satisfaction (net of the effects of their own goals), as did men whose partners gave priority to pro-social goals/values. Also men whose partners gave a high priority to material goals had significantly lower life satisfaction.

In Britain and Australia, where goals were less well measured, results are less clear. Indeed, in the British data, there are no significant relationships between partner goals and a person's own life satisfaction, once the effects of his/her own goals have been taken into account. In Australia there are small but statistically significant $(\mathrm{p}<0.05)$ links for both men and women between having a partner with pro-social goals and greater life satisfaction. For women it also appears to be important to have a partner who gives high priority to family values.

\section{Actual and preferred working hours, social participation and healthy lifestyle}

Next, we consider three choices which, in terms of causal ordering, may be regarded as consequences of both personality traits and life goals. First, the trade-off (perhaps constrained by job availability) between work and leisure. Recall that, in the Australian and German datasets, we classify individuals whose actual working time per week is within three hours of their preferred time as having their preferences met. We treat those who work over three hours more than they want as 'overworked', and those who work over three hours less than they want as 'underworked'. (In the case of British employees, we only know whether they would prefer more hours, fewer hours, or the same as they are currently working). Two other groups are also included in the analyzes: unemployed people who are actively seeking work and people not currently in the labor force.

A second choice whose consequences are shown in Table 3 is the choice to be more or less active in social interactions with friends, neighbors and relatives. A further choice is to be active in sport and/or in taking regular exercise.

\section{INSERT TABLE 3 FOR EACH COUNTRY HERE}


The evidence in Table 3 indicates that most people who work more or fewer hours than they want are significantly less satisfied with life than those who come close to making their preferred trade-off between work and leisure. That said, there are some interesting national differences. For Germans being 'underworked' is worse than being 'overworked', but for Australians and Britons being overworked has a more depressing effect on life satisfaction. German women apparently do not mind being overworked (or, to be exact, for them the relationship between overwork and life satisfaction is not statistically significant), whereas British women do not mind being underworked. Being involuntarily unemployed has much the strongest negative effect.

For all three countries, it is also clear from Table 3 that both the choice to engage in a range of social activities in one's leisure time, and the choice to exercise relatively frequently, can have substantial effects on life satisfaction. The first of these results can be regarded as confirming previous research by Bradburn (1969) and more generally Putnam (2000), while the second confirms repeated findings in the public health literature. The somewhat new contribution here is to show that both results hold net of personality traits.

A second measure of 'healthy lifestyle', BMI, can be added to the equations in Table 3, but just for recent years. ${ }^{11}$ In all three countries obese women have significantly lower life satisfaction than average, whereas obese men are close to the male average. ${ }^{12}$

A final piece of analysis is more precisely focused on the issue of whether changes in life choices produce changes in life satisfaction. Table 4 gives results of fixed effects equations, rather than the random effects equations shown in previous tables. In the fixed effects model only within-person changes over time are analyzed. An advantage of this model, which can only be used when a reasonably long series of repeated measures is available, is that all variables which, from a within-person point of view, are time

\footnotetext{
${ }^{11}$ Consequently an annual measure of life satisfaction, rather than a 5-year or 3-year average measure, serves as the dependent variable.

${ }^{12}$ In Australia the metric regression coefficient for obese women is -0.08 ( $\left.p<0.01\right)$, in Britain $b=-0,21$ $(\mathrm{p}<0.001)$ and in Germany $\mathrm{b}=-0.21(\mathrm{p}<0.01)$.
} 
invariant are 'controlled' ${ }^{13}$ So in Table 4 we can think of all genetic factors which affect SWB as being controlled, not just personality traits.

\section{INSERT TABLE 4 FOR EACH COUNTRY HERE}

This final set of results indicates that, for most people in all three countries, changes over time in levels of social participation and exercise, and in the fit between actual and preferred working hours, co-vary with changes in life satisfaction. ${ }^{14}$ In other words, choices about these three matters have statistically significant effects on SWB, net of the effects of all genetic and other time invariant factors. It is recognized that the $\mathrm{R}^{2}$ statistics (variance explained) in these tables might appear quite low, but this is normal for fixed effects equations in which only within-person variance (and not between-person variance) is accounted for. Issues to do with the substantive and theory related importance of these results are taken up in the next section.

\section{DISCUSSION}

Integrating results: choice of partner, life goals, working hours, leisure activities and healthy lifestyle

The results in this paper show that five sets of choices make a substantial difference to life satisfaction. Key preferences and choices relate to one's partner, life goals/values, the trade-off between work and leisure, social participation and healthy lifestyle. Results for the three countries replicate quite closely despite the fact that there were some differences in question wording and response scales for both the dependent variable (life satisfaction) and all explanatory variables measuring preferences and choices.

\footnotetext{
${ }^{13}$ In previous tables, dealing with personality traits and life goals, assumptions required for a fixed effects model were not met. Personality traits have only been measured once in SOEP, and life goals on only a few occasions and at uneven intervals.

14 The same exceptions apply as in Table 3: German women appear not to mind being overworked and British women do not mind being underworked. Also, in the case of British men, there is no significant link between changes in social participation and changes in life satisfaction (although the coefficient is positive).
} 
Life goals and some choices have as much or more impact on life satisfaction than extroversion and being married/partnered' two variables highlighted in previous research as important to SWB. It is clear that partner's level of neuroticism, and one's own commitment to family and pro-social goals, participation in social activities and regular exercise, are as important or more important to an individual's SWB than being extroverted. ${ }^{15}$ For women, being obese appears to more dissatisfying than not having a partner. Being underworked or overworked is, however, less serious!

These results have major implications for SWB theory. In order to understand the implications more clearly, it helps to understand how the choices are linked. First, as several researchers have noted, the life satisfaction levels of partners/married people are strongly positively correlated (Winkelmann, 2004; Schimmack and Lucas, 2010). It is not completely obvious that the reason for this positive relationship is that happy people make each other happier, while miserable people make each other more miserable. An alternative explanation lies in the well established finding that people with similar personality traits tend to partner/marry each other. So it is on average true that people with personalities favourable to SWB (low N, high E etc) tend to partner, as do people with personalities harmful to happiness. Such results in themselves could partly explain the positive correlations between the SWB levels of partners. However, in this paper it has been shown (Table 1 for each country) that something more is involved and that partners do promote or damage each other's longer term SWB. That is, the personality of one's partner contributes to SWB over and above the effects of one's own personality. As reported earlier, this result is unaffected by the degree of similarity or difference between the traits of partners.

These findings about partners suggest that SWB researchers should probably go back to Lucas et al's (2003) original view that, after getting married, some individuals record long term gains in SWB, while others show long term losses. The later view of the same

\footnotetext{
${ }^{15}$ These benchmark assessments are made on the basis of re-running analyses with standardized variables and coefficients (Betas). That is, variables were rescaled to have means of zero and standard deviations of one. Rough comparisons can then be made between the effect sizes of regression coefficients, because they have all had the same metric imposed.
} 
authors, namely that marriage is just one of many life events that only produces a temporary (in this case upward) fluctuation in life satisfaction, seems incorrect (Clark, Diener and Lucas, 2008). The long term SWB of individuals who partner/marry a person with a similar personality to themselves is unlikely to change, but those who marry someone with a more 'favorable' personality record gains, while those who partner someone with an unfavourable personality show losses. These outcomes are in line with Gottman's celebrated longitudinal and case study research on marital satisfaction documented in The Marriage Clinic (1997). They are also, but misleadingly, compatible with finding that the average effect of the life event of 'getting married' is zero.

The results in this paper relating to the impact of partner's life goals/values on SWB build on previous results suggesting that an individual's own life goals/values matter (Emmons, 1986; Headey, 2008b). It clearly runs counter to set-point theory to find that the extent to which both self and partner attach priority to pro-social goals/values affects SWB. A proponent of set-point theory might perhaps speculate that the goals one espouses are partly genetically determined. But it stretches belief to imagine that a partner's life goals could be strongly influenced by an individual's own genetic make-up. However, a very indirect and so presumably weak link is possible. It might be that genes, and personality traits in particular, create a predisposition to find a partner with similar traits to oneself, and that 'his' and 'her' genes both then predispose towards similar life goals. In this context it should be noted that there are moderate correlations in all three datasets between the life goals of partners. Even so, although genes might be indirectly implicated, it is important to remember the point that geneticists routinely make...genes are not destiny, they just create predispositions.

Putting results together, it is important to see that there are quite strong and readily interpretable associations among all the variables linked to life satisfaction. Individuals who themselves rate low on $\mathrm{N}$ and high on $\mathrm{E}, \mathrm{A}$ and $\mathrm{C}$ tend to partner/marry people with similar traits, and these partners also have similar life goals. Further, ratings on both traits and goals are associated with activities which promote SWB, namely greater social participation and a healthy lifestyle. In particular, trait $\mathrm{E}$ (and also $\mathrm{O}$ ) is moderately 
associated with pro-social life goals/values and with greater participation in social activities. The link between pro-social goals and active social participation suggests that self-reported goals are more than just abstract statements (or idealized self-images) and have plausible connections to actual behavior. In making this point, it is not assumed that all causation runs in one direction. It is likely that repeated patterns of behavior influence life goals, as well as vice-versa.

\section{SWB theory: moving towards a theory of long term stability and change}

On the basis of data from all three panels, it seems almost indisputable that a substantial minority of people record long term, more or less permanent changes in their levels of SWB. So one key challenge for researchers is to try and build a theory which accounts for medium and long term change, as well as stability. Plainly set-point theory, as currently understood, only accounts for stability.

The focus of this article has been on individual choices which affect SWB. It has been found that choices relating to partnering, life goals/values, hours of work (and, by implication, leisure), social and community participation and health make a substantial difference. It appears that giving relatively high priority to life domains in which it is usual to pursue non zero sum goals is a better recipe for happiness than giving priority to domains in which goal pursuit involves gains for some at the expense of losses for others. Non zero sum domains (broadly speaking) include partnering and family life, social and community participation, and health. Zero sum goals (again broadly speaking) include those relating to career advancement, enhanced status and material gains.

Attributing behavior to individual 'choice' is often regarded as dubious in the social sciences (with the clear exception of economics). Plainly, many behaviors are subject to constraints, both economic and social. But choices relating to partner personality traits, life goals/values, social participation and healthy lifestyle appear not to be tightly constrained. An apparent but by no means watertight inference is that some (perhaps many) people could change their life choices with beneficial consequences for their happiness. This inference is not watertight because much of the evidence in this paper 
has related to between-person differences, not within-person changes over time. There are many notorious examples, especially in health research, of benefits inferred from between-person research not translating into significant within-person gains (Ebrahim and Smith, 1997). So it will be important in future SWB research to obtain further longitudinal evidence, perhaps of an experimental or quasi-experimental kind (since we may have to wait a long time for panel data), on the effects of changes in choices on subsequent SWB. The key task, however, is theory development; new theoretical insights are essential to guide data collection and analysis. We are far from having a behavioral theory of happiness; a theory which accounts for change as well as stability in happiness levels. 


\section{References}

Andrews, F.M. and Withey, S.B. (1976) Social Indicators of Well-Being. New York, Plenum.

Barrick, M.R. and Mount, M.K. (1991) The Big Five Personality Dimensions And Job Performance: A Meta-Analysis, Personnel Psychology, 44, 1-26.

Bradburn, N.M. (1969) The Structure of Psychological Well-Being. Chicago, Aldine.

Brickman, P.D. and Campbell, D.T. (1971) 'Hedonic relativism and planning the good society' in M.H. Appley ed. Adaptation Level Theory. New York, Academic Press.

Campbell, A., Converse, P.E. and Rodgers, W.R. (1976) The Quality of American Life. New York, Sage.

Clark, A.E., Georgellis, Y., Lucas, R.E. \& Diener, E. (2004) Unemployment alters the set point for life satisfaction, Psychological Science, 15, 8-13.

Clark, A.E., Diener, E., Georgellis, Y. and Lucas, R.E. (2008) Lags and leads in life satisfaction: A test of the baseline hypothesis, Economic Journal, 118, 222-43.

Costa, P.T. and McCrae, R.R. (1980) Influences of extroversion and neuroticism on subjective well-being, Journal of Personality and Social Psychology, 38, 668-78.

Costa, P.T. and McCrae, R.R. (1991) The NEO PI-R. Odessa, Fl., PAR.

Diener, E., Lucas, R.E. and Scollon, C. (2006) Beyond the hedonic treadmill: Revising the adaptation theory of well-being, Psychological Science, 61, 305-14.

Diener, E., Suh, E.M., Lucas, R.E. \& Smith, H.L. (1999) Subjective well-being: Three decades of progress, Psychological Bulletin, 25, 276-302.

Diener, E. and Seligman, M.E.P. (2004) Beyond money: Toward an economy of wellbeing, Psychological Science in the Public Interest, 5, 1-31.

Diener, E. and Biswas-Diener, R. (2008) Happiness: Unlocking The Mysteries Of Psychological Wealth. Oxford, Blackwell.

Dunn, E.W., Aknin, L.B. and Norton, M.I. (2008) Spending money on others promotes happiness, Science, 319, 1687-88.

Easterlin, R.A. (2005) 'Building a better theory of well-being' in L. Bruni and P. Porta eds. Economics and Happiness: Framing the Analysis. Oxford, Oxford Univ. Press. 
Ebrahim, S. and Smith, G.D. (1997) Systematic review of randomized control trials of multiple risk factor interventions for preventing coronary heart disease, British Medical Journal, 314, 1666.

Emmons, R.A. (1986) Personal strivings: An approach to personality and subjective wellbeing, Journal of Personality and Social Psychology, 51, 1058-68.

Erhardt, J.J., Saris, W.E. and Veenhoven, R. (2000) Life-satisfaction over time: analysis of changes in ranks in a national population, Journal of Happiness Studies, 1, 177-205.

Frank, R.H. (1985) The demand for unobservable and other nonpositional goods, American Economic Review, 75, 279-301.

Frey, B.S. and Stutzer, A. (2002) What can economists learn from happiness research? Journal of Economic Literature, 40, 402-35.

Fujita, F. and Diener (2005) Life satisfaction set-point: Stability and change. Journal of Personality and Social Psycholgy, 88, 158-64.

Gerlitz, J.-Y. \& Schupp, J. (2005) Zur Erhebung der Big-Five-basierten Persoenlichkeitsmerkmale im SOEP. www.diw.de/deutsche/produkte/publikationen/researchnotes/docs/papers/rn4.pdf.

Gerstorf, D., Ram, N., Hidajat, M., Mayraz, G., Lindenberger, U., Schupp, J. and Wagner, G. G. (2010) Late-life decline in well-being across adulthood in Germany, the UK, and the US: something is seriously wrong at the end of life, Psychology and Aging, 25, 477-85.

Gigerenzer, G. (2010) Personal Reflections on Theory and Psychology, Theory and Psychology, 20, 733-43.

Gottman, J.M. (1997) The Marriage Clinic: A Scientifically-Based Marital Therapy. New York, Norton.

Harlow, R.E. and Cantor, N. (1996) Still participating after all these years: A study of life task participation in later life, Journal of Personality and Social Psychology, 71, 1235-49. 
Headey, B.W. and Wearing, A.J. (1989) Personality, life events and subjective wellbeing: Towards a dynamic equilibrium model, Journal of Personality and Social Psychology, 57, 731-39.

Headey, B.W. (2006) Subjective well-being: Revisions to dynamic equilibrium theory using national panel data and panel regression methods, Social Indicators Research, 79, 369-403.

Headey, B.W. (2008a) The set-point theory of well-being: Negative results and consequent revisions, Social Indicators Research, 85, 389-403.

Headey, B.W. (2008b) Life goals matter to happiness: A revision of set-point theory, Social Indicators Research, 86, 213-31.

Headey, B.W., Muffels, R.J.A. and Wagner, G.G. (2010) Long-running German panel survey shows that personal and economic choices, not just genes, matter for happiness, Proceedings of the National Academy of Sciences, 107.42, 1792217926 (Oct. 19).

Hirsch, F. (1976) Social Limits to Growth. Cambridge, Ma., Harvard Univ. Press. Huppert, F. (2005) Positive mental health in individuals and populations in F. Huppert, Baylis, N. and Keverne, B. The Science of Well-Being, Oxford, Oxford Univ. Press, pp. 307-40.

Kasser, T. and Kanner, A.D. eds. (2004) Psychology and Consumer Culture: The Struggle for the Good Life in a Materialistic World. Washington D.C., American Psychological Association.

Kluckhohn, F.R. and Strodtbeck, F.L. (1961) Variations in Value Orientations. Evanston, Illinois: Row, Peterson.

Kroh, M. (2005) Intervieweffekte bei der Erhebung des Körpergewichts in Bevölkerungsumfragen. Gesundheitswesen, 67: 646-655.

Larsen, R.J. (1992) Neuroticism and selective encoding and recall of symptoms: Evidence from a combined concurrent-retrospective study. Journal of Personality and Social Psychology, 62, 489-98.

Larsen, R.J. and Ketelaar, T. (1991) Personality and susceptibility to positive and negative emotional states. Journal of Personality and Social Psychology, 61, 13240. 
Lucas, R.E., Clark, A.E., Georgellis, Y. \& Diener, E. (2003) Reexamining adaptation and the set point model of happiness: Reactions to change in marital status, Journal of Personality and Social Psychology, 84, 527-39.

Lucas, R.E. and Baird, B.M. (2004) Extraversion and emotional reactivity, Journal of Personality and Social Psychology, 86, 473-85.

Lucas, R.E. (2007) Long-term disability is associated with lasting changes in subjective well-being: evidence from two nationally representative longitudinal studies, Journal of Personality and Social Psychology, 92, 717-30.

Lucas, R.E. and Donnellan, M.B. (2007) How stable is happiness? Using the STARTS model to estimate the stability of life satisfaction, Journal of Research in Personality, 41, 1091-98.

Lucas, R.E. (2008) Personality and subjective well-being in M. Eid and R.J. Larsen eds. The Science of Subjective Well-Being. New York, Guilford Press, 171-94.

Lykken, D. and Tellegen, A. (1996) Happiness is a stochastic phenomenon, Psychological Science, 7, 186-89.

Lykken, D. (1999) Happiness: What studies on twins show us about nature, nurture and the happiness set-point. New York: Golden Books.

Lynn, P. (2006) Quality Profile: BHPS Version 2.0: Waves 1 to 13 1991-2003. University of Essex, Institute for Social Research.

Lyubomirsky, S. (2008) The How of Happiness: A Scientific Approach to Getting the Life You Want. New York, Penguin.

Mehnert, T., Kraus, H.H., Nadler, R. and Boyd, M. (1990) Correlates of life satisfaction in those with a disabling condition, Rehabilitation Psychology, 35, 3-17.

Nickerson, C., Schwarz, N., Diener, E. and Kahneman, D. (2003) Zeroing in on the dark side of the American dream: A closer look at the negative consequences of the goal for financial success, Psychological Science, 14, 531-36.

Putnam, R.D. (2000) Bowling Alone: The Collapse and Revival of American Community. New York, Simon \& Schuster.

Roberts, B.W., Walton, K. and Viechtbauer, W. (2006) Patterns of mean-level change in personality traits across the life course: A meta-analysis of longitudinal studies, Psychological Bulletin, 132, 3-27. 
Robins, R.W., Caspi, A. and Moffitt, T.E. (2000) Two personalities, one relationship: Both partners' personality traits shape the quality of their relationship, Journal of Personality and Social Psychology, 79, 251-59.

Rusting, C.L. and Larsen, R.J. (1997) Extraversion, neuroticism and susceptibility to positive and negative affect. Personality and Individual Differences, 22, 607-12.

Saucier, G. (1994) Mini-markers: a brief version of Goldberg's Big Five markers, Journal of Personality Assessment, 63, 506-16.

Schimmack, U. and Lucas, R.E. (2010) Environmental influences on subjective wellbeing: a dyadic latent panel analysis of spousal similarity, Social Indicators Research, 98, 1-21.

Scollon, C.N. and Diener, E. (2006) Love, work and changes in extraversion and neuroticism over time, Journal of Personality and Social Psychology, 91, 115265.

Thoits, P.A. and Hewitt, L.N. (2001) Volunteer work and well-being, Journal of Health and Social Behavior, 42, 115-31.

Wagner, G.G., Frick, J. R., and Schupp, J. (2007) The German Socio-Economic Panel Study (SOEP) - Scope, Evolution and Enhancements. Schmollers Jahrbuch 127 (1), 139-169.

Watson, N. and Wooden, M. (2004) Assessing the quality of the HILDA Survey Wave 2 data. Melbourne, Melbourne Institute of Applied Economic and Social Research.

Winkelmann, R. (2004) Subjective well-being and the family: results from an ordered probit model with multiple random effects, IZA Discussion Paper No. 1016.

Wortman, C.B. and Silver, R.C. (1987) Coping with irrevocable loss. In G.R. Vanderbos and B.K. Bryant (Eds.), Cataclysms, crises, catastrophes: psychology in action. Washington, D.C., APA. 


\section{TABLES}


Table 1: Australia (HILDA Panel Survey)

Effects of Own Personality and Partner's Personality on Life Satisfaction: GLS Random

Effects Panel Regressions (metric coefficients, p-values based on robust standard errors)

\begin{tabular}{|c|c|c|c|}
\hline & $\begin{array}{c}\text { All: } \\
\text { Personality + } \\
\text { Controls }^{\mathrm{a}}\end{array}$ & $\begin{array}{c}\text { Partnered Men: } \\
\text { As before + } \\
\text { Partner Personality }^{\mathrm{a}}\end{array}$ & $\begin{array}{l}\text { Partnered Women: } \\
\text { As before }+ \\
\text { Partner Personality }^{\mathrm{a}}\end{array}$ \\
\hline Neuroticism & $-0.20 * * *$ & $-0.12 * * *$ & $-0.20 * * *$ \\
\hline Extroversion & $0.12 * * *$ & $0.11 * * *$ & $0.11 * * *$ \\
\hline Openness & $-0.06 * * *$ & $-0.06 *$ & $-0.04 *$ \\
\hline Agreeableness & $0.13 * * *$ & $0.16 * * *$ & $0.12 * * *$ \\
\hline Conscientiousness & $0.08 * * *$ & $0.10 * * *$ & $0.06 * *$ \\
\hline Partner Neuroticism & & $-0.07 * *$ & $-0.08 * * *$ \\
\hline Partner Extroversion & & $0.06 * * *$ & 0.03 \\
\hline $\begin{array}{c}\text { Partner } \\
\text { Openness }\end{array}$ & & 0.02 & 0.00 \\
\hline $\begin{array}{c}\text { Partner } \\
\text { Agreeableness }\end{array}$ & & 0.04 & 0.03 \\
\hline $\begin{array}{c}\text { Partner } \\
\text { Conscientiousness }\end{array}$ & & $0.05 *$ & $0.05 * *$ \\
\hline Adj. R squared & $13.0 \%$ & $10.9 \%$ & $11.7 \%$ \\
\hline $\mathrm{N}$ & 55479 & 17652 & 18359 \\
\hline
\end{tabular}

a. All results (coefficients) are net of gender, age, age squared, age cubed, partner status (1-0), unemployed (1-0), health disability (1-0), NESB (1-0), the national unemployment rate and a count variable measuring the number of years respondents had already participated in the survey. $* * *$ significant at $0.001 * *$ significant at $0.01 *$ significant at 0.05 
Table 1: Britain (BHPS)

Effects of Own Personality and Partner's Personality on Life Satisfaction: GLS Random

Effects Panel Regressions (metric coefficients, p-values based on robust standard errors)

\begin{tabular}{|c|c|c|c|}
\hline & $\begin{array}{c}\text { All: } \\
\text { Personality + } \\
\text { Controls }^{\mathrm{a}}\end{array}$ & $\begin{array}{c}\text { Partnered Men: } \\
\text { As before + } \\
\text { Partner Personality }^{\mathrm{a}}\end{array}$ & $\begin{array}{l}\text { Partnered Women: } \\
\text { As before + } \\
\text { Partner Personality }^{\mathrm{a}}\end{array}$ \\
\hline Neuroticism & $-0.40 * * *$ & $-0.34 * * *$ & $-0.36 * * *$ \\
\hline Extroversion & $0.08 * * *$ & $0.07 * * *$ & 0.04 \\
\hline Openness & -0.01 & 0.02 & -0.04 \\
\hline Agreeableness & $0.13 * * *$ & $0.13 * * *$ & $0.17 * * *$ \\
\hline Conscientiousness & $0.20 * * *$ & $0.24 * * *$ & $0.14 * * *$ \\
\hline Partner Neuroticism & & $-0.10 * * *$ & $-0.11 * * *$ \\
\hline Partner Extroversion & & 0.01 & -0.01 \\
\hline $\begin{array}{c}\text { Partner } \\
\text { Openness }\end{array}$ & & 0.01 & 0.02 \\
\hline $\begin{array}{c}\text { Partner } \\
\text { Agreeableness }\end{array}$ & & 0.02 & $0.06^{*}$ \\
\hline $\begin{array}{c}\text { Partner } \\
\text { Conscientiousness }\end{array}$ & & 0.01 & $0.06^{*}$ \\
\hline Adj. R squared & $20.3 \%$ & $19.2 \%$ & $17.0 \%$ \\
\hline $\mathrm{N}$ & 73971 & 24141 & 25315 \\
\hline
\end{tabular}

b. All results (coefficients) are net of gender, age, age squared, age cubed, partner status (1-0), unemployed (1-0), health disability (1-0), non-white (1-0), the national unemployment rate and a count variable measuring the number of years respondents had already participated in the survey.

$* * *$ significant at $0.001 * *$ significant at $0.01 *$ significant at 0.05 
Table 1: Germany (SOEP)

Effects of Own Personality and Partner's Personality on Life Satisfaction: GLS Random Effects Panel Regressions (metric coefficients, p-values based on robust standard errors)

\begin{tabular}{|c|c|c|c|}
\hline & $\begin{array}{c}\text { All: } \\
\text { Personality + } \\
\text { Controls }^{\mathrm{a}}\end{array}$ & $\begin{array}{c}\text { Partnered Men: } \\
\text { As before + } \\
\text { Partner Personality }\end{array}$ & $\begin{array}{c}\text { Partnered Women: } \\
\text { As before + } \\
\text { Partner Personality }\end{array}$ \\
\hline Neuroticism & $-0.27 * * *$ & $-0.25 * * *$ & $-0.21 * * *$ \\
\hline Extroversion & $0.07 * * *$ & $0.06 * * *$ & $0.07 * * *$ \\
\hline Openness & $0.07 * * *$ & $0.05^{* *}$ & 0.05 \\
\hline Agreeableness & $0.07 * * *$ & $0.07 * * *$ & $0.07 * *$ \\
\hline Conscientiousness & $0.06 * * *$ & $0.06 * *$ & 0.04 \\
\hline Partner Neuroticism & & $-0.06 * * *$ & $-0.06 * *$ \\
\hline Partner Extroversion & & -0.00 & -0.02 \\
\hline $\begin{array}{c}\text { Partner } \\
\text { Openness }\end{array}$ & & $0.04 *$ & 0.03 \\
\hline $\begin{array}{c}\text { Partner } \\
\text { Agreeableness }\end{array}$ & & -0.00 & -0.01 \\
\hline $\begin{array}{c}\text { Partner } \\
\text { Conscientiousness }\end{array}$ & & 0.02 & 0.01 \\
\hline Adj. R squared & $20.9 \%$ & $21.6 \%$ & $19.2 \%$ \\
\hline $\mathrm{N}$ & 157771 & 59230 & 62712 \\
\hline
\end{tabular}

c. All results (coefficients) are net of gender, age, age squared, age cubed, partner status (1-0), unemployed (1-0), health disability (1-0), East German (1-0), foreign (1-0), the national unemployment rate and a count variable measuring the number of years respondents had already participated in the survey.

$* * *$ significant at $0.001 * *$ significant at $0.01 *$ significant at 0.05 
Table 2: Australia

Effects of Own Life Goals and Partner's Life Goals on Life Satisfaction: GLS Random

Effects Panel Regression Analyzes (metric coefficients, p-values based on robust standard errors)

\begin{tabular}{|c|c|c|c|}
\hline & $\begin{array}{c}\text { All: } \\
\text { Personality } \\
+ \text { Life Goals } \\
+ \text { Controls }^{\mathrm{a}}\end{array}$ & $\begin{array}{c}\text { Partnered Men: } \\
\text { As before } \\
\text { + Partner Life } \\
\text { Goals }^{\mathrm{a}}\end{array}$ & $\begin{array}{c}\text { Partnered Women: } \\
\text { As before } \\
+ \text { Partner Life } \\
\text { Goals }^{\mathrm{a}}\end{array}$ \\
\hline Neuroticism & $-0.21 * * *$ & $-0.13 * * *$ & $-0.21 * * *$ \\
\hline Extroversion & $0.11 * * *$ & $0.09 * * *$ & $0.10 * * *$ \\
\hline Openness & $-0.06 * * *$ & $-0.06 *$ & -0.04 \\
\hline Agreeableness & $0.08 * * *$ & $0.12 * * *$ & $0.10 * *$ \\
\hline Conscientiousness & $0.08 * * *$ & $0.08 * * *$ & $0.05 *$ \\
\hline Partner Neuroticism & & $-0.06 *$ & $-0.09 * * *$ \\
\hline Partner Extroversion & & $0.06 *$ & 0.01 \\
\hline Partner Openness & & 0.04 & -0.01 \\
\hline Partner Agreeableness & & 0.04 & 0.00 \\
\hline $\begin{array}{c}\text { Partner } \\
\text { Conscientiousness }\end{array}$ & & 0.04 & $0.05 *$ \\
\hline Social/Altruistic Goals & $0.07 * * *$ & $0.07 * * *$ & $0.05 * * *$ \\
\hline Family Goals & $0.06 * * *$ & $0.09 * * *$ & $0.07 *$ \\
\hline Material Goals & 0.01 & $0.04 *$ & 0.02 \\
\hline $\begin{array}{c}\text { Partner } \\
\text { Social/Altruistic Goals }\end{array}$ & & $0.02 *$ & $0.02 *$ \\
\hline Partner Family Goals & & -0.03 & $0.06 * *$ \\
\hline $\begin{array}{c}\text { Partner Material } \\
\text { Goals }\end{array}$ & & -0.01 & -0.01 \\
\hline $\mathrm{R}_{\text {squared }} \mathrm{b}$ & $14.7 \%$ & $12.8 \%$ & $13.2 \%$ \\
\hline $\mathrm{N}$ & 51758 & 14979 & 15786 \\
\hline
\end{tabular}


a. All results (coefficients) are net of gender, age, age squared, age cubed, partner status (1-0), unemployed (1-0), health disability (1-0), NESB (1-0), the national unemployment rate and a count variable measuring the number of years respondents had already participated in the survey.

b. The $\mathrm{R}^{2}$ reported here is a weighted average of variance accounted for 'between persons' and 'within persons'.

$* * *$ significant at $0.001 * *$ significant at $0.01 *$ significant at 0.05 
Table 2: Britain (BHPS)

Effects of Own Life Goals and Partner's Life Goals on Life Satisfaction: GLS Random

Effects Panel Regression Analyzes (metric coefficients, p-values based on robust standard errors)

\begin{tabular}{|c|c|c|c|}
\hline & $\begin{array}{c}\text { All: } \\
\text { Personality } \\
+ \text { Life Goals } \\
+ \text { Controls }^{\mathrm{a}}\end{array}$ & $\begin{array}{c}\text { Partnered Men: } \\
\text { As before } \\
+ \text { Partner Life } \\
\text { Goals }^{\mathrm{a}}\end{array}$ & $\begin{array}{c}\text { Partnered Women: } \\
\text { As before } \\
+ \text { Partner Life } \\
\text { Goals }^{\mathrm{a}}\end{array}$ \\
\hline Neuroticism & $-0.40 * *$ & $-0.34 * * *$ & $-0.37 * * *$ \\
\hline Extroversion & $0.05 * *$ & $0.07 *$ & 0.01 \\
\hline Openness & $-0.05 * *$ & -0.00 & $-0.08 *$ \\
\hline Agreeableness & $0.09 * * *$ & $0.09 *$ & $0.08 *$ \\
\hline Conscientiousness & $0.19 * * *$ & $0.20 * * *$ & $0.14 * * *$ \\
\hline Partner Neuroticism & & $-0.11 * * *$ & $-0.08 * * *$ \\
\hline Partner Extroversion & & -0.04 & -0.03 \\
\hline Partner Openness & & 0.03 & 0.04 \\
\hline Partner Agreeableness & & -0.01 & $0.07 *$ \\
\hline $\begin{array}{c}\text { Partner } \\
\text { Conscientiousness }\end{array}$ & & -0.02 & 0.06 \\
\hline Social/Altruistic Goals & $0.11 * * *$ & $0.10 * * *$ & $0.13 * * *$ \\
\hline Family Goals & $0.10 * * *$ & $0.12 *$ & $0.22 * * *$ \\
\hline Material Goals & $-0.04 * * *$ & -0.04 & $-0.05^{*}$ \\
\hline $\begin{array}{c}\text { Partner } \\
\text { Social/Altruistic Goals }\end{array}$ & & 0.03 & 0.03 \\
\hline Partner Family Goals & & -0.00 & -0.02 \\
\hline $\begin{array}{c}\text { Partner Material } \\
\text { Goals }\end{array}$ & & -0.01 & -0.01 \\
\hline R squared $^{b}$ & $20.8 \%$ & $20.6 \%$ & $20.8 \%$ \\
\hline $\mathrm{N}$ & 39406 & 5839 & 6100 \\
\hline
\end{tabular}


c. All results (coefficients) are net of gender, age, age squared, age cubed, partner status (1-0), unemployed (1-0), health disability (1-0), non-white (1-0), the national unemployment rate and a count variable measuring the number of years respondents had already participated in the survey.

d. The $\mathrm{R}^{2}$ reported here is a weighted average of variance accounted for 'between persons' and 'within persons'.

$* * *$ significant at $0.001 * *$ significant at $0.01 *$ significant at 0.05 
Table 2: Germany (SOEP

Effects of Own Life Goals and Partner's Life Goals on Life Satisfaction: GLS Random Effects Panel Regression Analyzes (metric coefficients, p-values based on robust standard errors)

\begin{tabular}{|c|c|c|c|}
\hline & $\begin{array}{c}\text { All: } \\
\text { Personality } \\
+ \text { Life Goals } \\
+ \text { Controls }^{\mathrm{a}}\end{array}$ & $\begin{array}{c}\text { Partnered Men: } \\
\text { As before } \\
+ \text { Partner Life } \\
\text { Goals }^{\mathrm{a}}\end{array}$ & $\begin{array}{c}\text { Partnered Women: } \\
\text { As before } \\
\text { + Partner Life } \\
\text { Goals }^{\mathrm{a}}\end{array}$ \\
\hline Neuroticism & $-0.28 * * *$ & $-0.25 * * *$ & $-0.21 * * *$ \\
\hline Extroversion & $0.06 * * *$ & $0.06 * * *$ & $0.07 * *$ \\
\hline Openness & $0.06 * * *$ & 0.03 & 0.03 \\
\hline Agreeableness & $0.04 * * *$ & $0.05 * *$ & 0.05 \\
\hline Conscientiousness & $0.06 * * *$ & $0.06 * *$ & 0.05 \\
\hline Partner Neuroticism & & $-0.07 * * *$ & $-0.05 *$ \\
\hline Partner Extroversion & & -0.02 & -0.02 \\
\hline Partner Openness & & $0.04^{*}$ & 0.03 \\
\hline Partner Agreeableness & & -0.02 & -0.02 \\
\hline $\begin{array}{c}\text { Partner } \\
\text { Conscientiousness }\end{array}$ & & 0.02 & 0.02 \\
\hline Social/Altruistic Goals & $0.27 * * *$ & $0.19 * * *$ & $0.21 * * *$ \\
\hline Family Goals & $0.21 * * *$ & $0.15 * * *$ & $0.14 * *$ \\
\hline Material Goals & $-0.10 * * *$ & 0.03 & -0.06 \\
\hline $\begin{array}{c}\text { Partner } \\
\text { Social/Altruistic Goals }\end{array}$ & & $0.14 * *$ & 0.09 \\
\hline Partner Family Goals & & $0.15 * * *$ & $0.17 * *$ \\
\hline $\begin{array}{c}\text { Partner Material } \\
\text { Goals }\end{array}$ & & $-0.17 * * *$ & -0.09 \\
\hline $\mathrm{R}_{\text {squared }} \mathrm{b}$ & $22.4 \%$ & $23.7 \%$ & $21.0 \%$ \\
\hline
\end{tabular}




\begin{tabular}{|c|c|c|c|}
\hline $\mathrm{N}$ & 154710 & 57858 & 61427 \\
\hline
\end{tabular}

e. All results (coefficients) are net of gender, age, age squared, age cubed, partner status (1-0), unemployed (1-0), health disability (1-0), East German (1-0), foreign (1-0), the national unemployment rate and a count variable measuring the number of years respondents had already participated in the survey.

f. The $\mathrm{R}^{2}$ reported here is a weighted average of variance accounted for 'between persons' and 'within persons'.

$* * *$ significant at $0.001 * *$ significant at $0.01 *$ significant at 0.05 
Table 3: Australia (HILDA)

Effects of Working Hours, Social Participation and Healthy Lifestyle on Life Satisfaction: GLS Random Effects Panel Regressions (metric coefficients, p-values based on robust standard errors)

\begin{tabular}{|c|c|c|c|}
\hline & $\begin{array}{c}\text { All Respondents: } \\
\text { Own Personality + } \\
\text { Life Goals + } \\
\text { Work Hours + } \\
\text { Social } \\
\text { Participation + } \\
\text { Healthy Lifestyle }\end{array}$ & $\begin{array}{c}\text { Men: } \\
\text { Own Personality + } \\
\text { Life Goals + } \\
\text { Work Hours + } \\
\text { Social } \\
\text { Participation + } \\
\text { Healthy Lifestyle }^{\mathrm{a}}\end{array}$ & $\begin{array}{c}\text { Women: } \\
\text { Own Personality + } \\
\text { Life Goals + } \\
\text { Work Hours + } \\
\text { Social } \\
\text { Participation + } \\
\text { Healthy Lifestyle }^{\mathrm{a}}\end{array}$ \\
\hline Neuroticism & $-0.18 * * *$ & $-0.14 * * *$ & $-0.21 * * *$ \\
\hline Extroversion & $0.10 * * *$ & $0.11 * * *$ & $0.08 * * *$ \\
\hline Openness & $-0.07 * * *$ & $-0.07 * * *$ & $-0.06 * *$ \\
\hline Agreeableness & $0.09 * * *$ & $0.11 * * *$ & $0.06 *$ \\
\hline Conscientiousness & $0.07 * * *$ & $0.08 * * *$ & $0.06 * *$ \\
\hline Social/Altruistic Goals & $0.07 * * *$ & $0.06 * * *$ & $0.07 * * *$ \\
\hline Family Goals & $0.06 * * *$ & $0.06 * *$ & $0.05 *$ \\
\hline Material Goals & 0.01 & 0.02 & $-0.01 * * *$ \\
\hline $\begin{array}{l}\text { Employed but } \\
\text { underworked }^{b}\end{array}$ & $-0.12 * * *$ & $-0.15 * * *$ & $-0.11 * * *$ \\
\hline $\begin{array}{l}\text { Employed and } \\
\text { overworked }^{\text {b }}\end{array}$ & $-0.18 * * *$ & $-0.18 * *$ & $-0.17 * * *$ \\
\hline Unemployed $^{b}$ & $-0.42 * * *$ & $-0.39 * * *$ & $-0.44 * * *$ \\
\hline Not in labor force ${ }^{b}$ & 0.06 & 0.00 & 0.12 \\
\hline Social Participation & $0.06 * * *$ & $0.05 * * *$ & $0.07 * * *$ \\
\hline Exercise: Frequency & $0.04 * * *$ & $0.03 * * *$ & $0.05 * * *$ \\
\hline R-squared ${ }^{\mathrm{d}}$ & $15.7 \%$ & $15.8 \%$ & $15.9 \%$ \\
\hline
\end{tabular}




\begin{tabular}{|c|c|c|c|}
\hline $\mathrm{N}$ & 36191 & 18565 & 17626 \\
\hline
\end{tabular}

a. All results (coefficients) are net of gender, age, age squared, age cubed, partner status (1-0), unemployed (1-0), health disability (1-0), NESB (1-0), the national unemployment rate and a count variable measuring the number of years respondents had already participated in the survey.

b. The $\mathrm{R}^{2}$ reported here is a weighted average of variance accounted for 'between persons' and 'within persons'.

*** significant at $0.001 * *$ significant at $0.01 *$ significant at 0.05 
Table 3: Britain (BHPS)

Effects of Working Hours, Social Participation and Healthy Lifestyle on Life Satisfaction: GLS Random Effects Panel Regressions (metric coefficients, p-values based on robust standard errors)

\begin{tabular}{|c|c|c|c|}
\hline & $\begin{array}{c}\text { All Respondents: } \\
\text { Own Personality + } \\
\text { Life Goals + } \\
\text { Work Hours + } \\
\text { Social } \\
\text { Participation + } \\
\text { Healthy Lifestyle }^{\mathrm{a}}\end{array}$ & $\begin{array}{c}\text { Men: } \\
\text { Own Personality + } \\
\text { Life Goals + } \\
\text { Work Hours + } \\
\text { Social } \\
\text { Participation + } \\
\text { Healthy Lifestyle }^{\mathrm{a}}\end{array}$ & $\begin{array}{c}\text { Women: } \\
\text { Own Personality + } \\
\text { Life Goals + } \\
\text { Work Hours + } \\
\text { Social } \\
\text { Participation + } \\
\text { Healthy Lifestyle }^{\mathrm{a}}\end{array}$ \\
\hline Neuroticism & $-0.37 * * *$ & $-0.35 * * *$ & $-0.38 * * *$ \\
\hline Extroversion & 0.03 & 0.04 & 0.02 \\
\hline Openness & $-0.06 * * *$ & $-0.07 * *$ & -0.05 \\
\hline Agreeableness & $0.12 * * *$ & $0.11 * * *$ & $0.13 * * *$ \\
\hline Conscientiousness & $0.16^{* * *}$ & $0.19 * * *$ & $0.12 * * *$ \\
\hline Social/Altruistic Goals & $0.12 * * *$ & $0.12 * * *$ & $0.12 * * *$ \\
\hline Family Goals & $0.08 * * *$ & $0.04 *$ & $0.11 * * *$ \\
\hline Material Goals & $-0.04 * * *$ & -0.03 & $-0.05 * *$ \\
\hline $\begin{array}{l}\text { Employed but } \\
\text { underworked }^{b}\end{array}$ & -0.05 & $-0.14 * * *$ & 0.02 \\
\hline $\begin{array}{c}\text { Employed and } \\
\text { overworked }^{\text {b }}\end{array}$ & $-0.08 * * *$ & $-0.07 * * *$ & $-0.09 * * *$ \\
\hline Unemployed $^{b}$ & -0.02 & -0.10 & -0.18 \\
\hline Not in labor force & 0.06 & 0.09 & 0.06 \\
\hline Social Participation & $0.05 * * *$ & $0.06 * * *$ & $0.04^{*}$ \\
\hline Exercise: Frequency & $0.04 * * *$ & $0.05 * * *$ & $0.03 *$ \\
\hline R-squared ${ }^{\mathrm{d}}$ & $18.7 \%$ & $19.7 \%$ & $18.5 \%$ \\
\hline
\end{tabular}




\begin{tabular}{|c|c|c|c|}
\hline $\mathrm{N}$ & 23901 & 11400 & 12501 \\
\hline
\end{tabular}

c. All results (coefficients) are net of gender, age, age squared, age cubed, partner status (1-0), unemployed (1-0), health disability (1-0), non-white (1-0), the national unemployment rate and a count variable measuring the number of years respondents had already participated in the survey.

d. The $\mathrm{R}^{2}$ reported here is a weighted average of variance accounted for 'between persons' and 'within persons'.

$* * *$ significant at $0.001 * *$ significant at $0.01 *$ significant at 0.05 
Table 3: Germany (SOEP)

Effects of Working Hours, Social Participation and Healthy Lifestyle on Life Satisfaction: GLS Random Effects Panel Regressions (metric coefficients, p-values based on robust standard errors)

\begin{tabular}{|c|c|c|c|}
\hline & $\begin{array}{c}\text { All Respondents: } \\
\text { Own Personality + } \\
\text { Life Goals + } \\
\text { Work Hours + } \\
\text { Social } \\
\text { Participation + } \\
\text { Healthy Lifestyle }^{\mathrm{a}}\end{array}$ & $\begin{array}{c}\text { Men: } \\
\text { Own Personality + } \\
\text { Life Goals + } \\
\text { Work Hours + } \\
\text { Social } \\
\text { Participation + } \\
\text { Healthy Lifestyle }^{\mathrm{a}}\end{array}$ & $\begin{array}{c}\text { Women: } \\
\text { Own Personality + } \\
\text { Life Goals + } \\
\text { Work Hours + } \\
\text { Social } \\
\text { Participation + } \\
\text { Healthy Lifestyle }^{\mathrm{a}}\end{array}$ \\
\hline Neuroticism & $-0.27 * * *$ & $-0.27 * * *$ & $-0.26 * * *$ \\
\hline Extroversion & $0.05 * * *$ & $0.05 * * *$ & $0.06 * * *$ \\
\hline Openness & $0.05 * * *$ & $0.05 * * *$ & $0.05 * * *$ \\
\hline Agreeableness & $0.04 * *$ & $0.05 * * *$ & $0.04 *$ \\
\hline Conscientiousness & $0.06 * * *$ & $0.06 * * *$ & $0.04 *$ \\
\hline Social/Altruistic Goals & $0.24 * * *$ & $0.23 * * *$ & $0.25 * * *$ \\
\hline Family Goals & $0.21 * * *$ & $0.19 * * *$ & $0.23 * * *$ \\
\hline Material Goals & $-0.10 * * *$ & -0.05 & $-0.14 * * *$ \\
\hline $\begin{array}{l}\text { Employed but } \\
\text { underworked }^{b}\end{array}$ & $-0.05 * * *$ & $-0.04 * * *$ & $-0.07 * * *$ \\
\hline $\begin{array}{l}\text { Employed and } \\
\text { overworked }^{\text {b }}\end{array}$ & $-0.02 * *$ & $-0.02 * *$ & 0.01 \\
\hline Unemployed $^{b}$ & $-0.31 * * *$ & $-0.36 * * *$ & $-0.27 * * *$ \\
\hline Not in labor force ${ }^{b}$ & -0.02 & $-0.14 * * *$ & 0.02 \\
\hline Social Participation & $0.09 * * *$ & $0.09 * * *$ & $0.09 * * *$ \\
\hline Exercise: Frequency & $0.03 * * *$ & $0.02 * * *$ & $0.03 * * *$ \\
\hline R-squared ${ }^{\mathrm{d}}$ & $22.1 \%$ & $23.2 \%$ & $21.0 \%$ \\
\hline
\end{tabular}




\begin{tabular}{|c|c|c|c|}
\hline $\mathrm{N}$ & 123044 & 64177 & 58867 \\
\hline
\end{tabular}

e. All results (coefficients) are net of gender, age, age squared, age cubed, partner status (1-0), unemployed (1-0), health disability (1-0), East German (1-0), foreign (1-0), the national unemployment rate and a count variable measuring the number of years respondents had already participated in the survey.

f. The $\mathrm{R}^{2}$ reported here is a weighted average of variance accounted for 'between persons' and 'within persons'.

*** significant at $0.001 * *$ significant at $0.01 *$ significant at 0.05 
Table 4: Australia (HILDA)

Changes in Working Hours, Social Participation and Healthy Lifestyle affect Changes in Life Satisfaction: Fixed Effects Panel Regressions (metric coefficients, p-values based on robust standard errors)

\begin{tabular}{|c|c|c|c|}
\hline & All Respondents $^{\mathrm{a}}$ & Men $^{\mathrm{a}}$ & Women $^{\mathrm{a}}$ \\
\hline $\begin{array}{c}\text { Employed but } \\
\text { underworked }^{\mathrm{b}}\end{array}$ & $-0.11^{* * *}$ & $-0.11^{* * * *}$ & $-0.01^{* * *}$ \\
\hline $\begin{array}{c}\text { Employed and } \\
\text { overworked }^{\mathrm{b}}\end{array}$ & $-0.15 * * *$ & $-0.14 * * *$ & $-0.15^{* * *}$ \\
\hline Unemployed $^{\mathrm{b}}$ & $-0.40^{* * *}$ & $-0.29 * * *$ & $-0.51^{* * *}$ \\
\hline Not in labor force $^{\mathrm{b}}$ & 0.06 & -0.09 & 0.22 \\
\hline Social Participation & $0.05 * * *$ & $0.05 * * *$ & $0.05^{* * *}$ \\
\hline Exercise: Frequency & $0.02 * * *$ & $0.02 * * *$ & $0.04 * * *$ \\
\hline R-squared & $7.3 \%$ & $8.0 \%$ & $6.0 \%$ \\
\hline $\mathrm{N}$ & 45697 & 23857 & 21787 \\
\hline
\end{tabular}

a. All results (coefficients) are net of age, age squared, age cubed, partner status (1-0), unemployed (1-0), health disability (1-0), NESB (1-0) and the national unemployment rate. The $\mathrm{R}^{2}$ reported here is a weighted average of variance accounted for 'between persons' and 'within persons'.

$* * *$ significant at $0.001 * *$ significant at $0.01 *$ significant at 0.05 
Table 4: Britain (BHPS)

Changes in Working Hours, Social Participation and Healthy Lifestyle affect Changes in Life Satisfaction: Fixed Effects Panel Regressions (metric coefficients, p-values based on robust standard errors)

\begin{tabular}{|c|c|c|c|}
\hline & All Respondents $^{\mathrm{a}}$ & Men $^{\mathrm{a}}$ & Women $^{\mathrm{a}}$ \\
\hline $\begin{array}{c}\text { Employed but } \\
\text { underworked }^{\mathrm{b}}\end{array}$ & $-0.05^{*}$ & $-0.12^{* * * *}$ & -0.00 \\
\hline $\begin{array}{c}\text { Employed and } \\
\text { overworked }^{\mathrm{b}}\end{array}$ & $-0.07^{* * *}$ & $-0.05^{* * *}$ & $-0.08^{* * *}$ \\
\hline Unemployed $^{\mathrm{b}}$ & -0.06 & 0.03 & -0.14 \\
\hline Not in labor force $^{\mathrm{b}}$ & 0.05 & 0.04 & 0.06 \\
\hline Social Participation & $0.04 * * *$ & 0.02 & $0.06^{* * *}$ \\
\hline Exercise: Frequency $^{\text {Sis }}$ & $0.03 * * *$ & $0.04 * * *$ & $0.03 *$ \\
\hline R-squared & $3.4 \%$ & $1.5 \%$ & $2.0 \%$ \\
\hline $\mathrm{N}$ & 42315 & 20085 & 22230 \\
\hline
\end{tabular}

b. All results (coefficients) are net of age, age squared, age cubed, partner status (1-0), unemployed (1-0), health disability (1-0), non-white (1-0) and the national unemployment rate. The $\mathrm{R}^{2}$ reported here is a weighted average of variance accounted for 'between persons' and 'within persons'.

$* * *$ significant at $0.001 * *$ significant at $0.01 *$ significant at 0.05 
Table 4: Germany (SOEP)

Changes in Working Hours, Social Participation and Healthy Lifestyle affect Changes in Life Satisfaction: Fixed Effects Panel Regressions (metric coefficients, p-values based on robust standard errors)

\begin{tabular}{|c|c|c|c|}
\hline & All Respondents $^{\mathrm{a}}$ & Men $^{\mathrm{a}}$ & Women $^{\mathrm{a}}$ \\
\hline $\begin{array}{c}\text { Employed but } \\
\text { underworked }^{\mathrm{b}}\end{array}$ & $-0.08^{* * *}$ & $-0.07 * * *$ & $-0.07 * * *$ \\
\hline $\begin{array}{c}\text { Employed and } \\
\text { overworked }^{\mathrm{b}}\end{array}$ & $-0.02^{*}$ & $-0.02^{* *}$ & -0.01 \\
\hline Unemployed $^{\mathrm{b}}$ & $-0.32^{* * *}$ & $-0.44^{* * *}$ & $-0.23 * * *$ \\
\hline Not in labor force $^{\mathrm{b}}$ & $-0.10^{* * *}$ & $-0.24 * * *$ & -0.03 \\
\hline Social Participation & $0.06 * * *$ & $0.07 * * *$ & $0.06 * * *$ \\
\hline Exercise: Frequency & $0.02 * * *$ & $0.03 * * *$ & $0.02 * * *$ \\
\hline R-squared & $5.3 \%$ & $7.6 \%$ & $4.3 \%$ \\
\hline $\mathrm{N}$ & 142390 & 69842 & 72548 \\
\hline
\end{tabular}

c. All results (coefficients) are net of age, age squared, age cubed, partner status (1-0), unemployed (1-0), health disability (1-0), East German (1-0), foreign (1-0) and the national unemployment rate. The $\mathrm{R}^{2}$ reported here is a weighted average of variance accounted for 'between persons' and 'within persons'.

$* * *$ significant at $0.001 * *$ significant at $0.01 *$ significant at 0.05 


\section{University Library}

\section{- M M N E R VA A gateway to Melbourne's research publications}

Minerva Access is the Institutional Repository of The University of Melbourne

Author/s:

Headey, B;Muffels, R;Wagner, GG

Title:

Choices Which Change Life Satisfaction: Similar Results for Australia, Britain and Germany

Date:

2013-07-01

Citation:

Headey, B., Muffels, R. \& Wagner, G. G. (2013). Choices Which Change Life Satisfaction: Similar Results for Australia, Britain and Germany. SOCIAL INDICATORS RESEARCH, 112 (3), pp.725-748. https://doi.org/10.1007/s11205-012-0079-8.

Persistent Link:

http://hdl.handle.net/11343/283214 